\title{
PREVENTION AND DETECTION OF FRAUD IN VILLAGE FUND SUPERVISION IN BARITO KUALA DISTRICT
}

\author{
Mellani Yuliastina ${ }^{*}$ \\ STIE Nasional Banjarmasin \\ 126, Mayjen Sutoyo S, Banjarmasin, \\ Indonesia 70115 \\ myuliastina@gmail.com
}

\author{
Muhammad Hudaya ${ }^{2}$ \\ Universitas Lambung Mangkurat \\ Brigjen H. Hasan Basri St., Banjarmasin, \\ Indonesia 70123 \\ mhudaya@ulm.ac.id
}

\author{
Wahyudin Nor ${ }^{3}$ \\ Universitas Lambung Mangkurat \\ Brigjen H. Hasan Basri St., Banjarmasin, \\ Indonesia 70123 \\ wahyudinnor@ulm.ac.id
}

\begin{abstract}
This study aims to map the village fund supervision system's pattern and detect the possibility of loopholes in the system. It can provide recommendations for strategy formulations that can prevent fraud in village fund management. This research uses qualitative methods with a case study research strategy. The results showed no fraud found in the three research objects, but the potential for fraud still exists and can change to be fraud due to lack of coordination of supervision between related institutions and unsolid whistleblowing system. This paper offers to strengthen internal control and whistleblowing system to address issues concerning the village fund supervision system.
\end{abstract}

Keywords: Village fund; Fraud; Fraud prevention; Fraud detection

\begin{abstract}
ABSTRAK
Tujuan penelitian ini adalah memetakan pola sistem pengawasan dana desa dan mendeteksi kemungkinan adanya celah (loopholes) fraud dari sistem tersebut sehingga dapat memberikan rekomendasi strategi yang mampu mencegah tindakan fraud pada pengelolaan dana desa. Penelitian ini menggunakan metode kualitatif dengan pendekatan studi kasus. Hasil penelitian menunjukkan bahwa tidak ada fraud yang ditemukan pada tiga objek penelitian, tetapi potensi fraud eksis dan bisa mengubah pada kondisi yang yang menyebabkan terjadinya fraud akibat belum optimalnya koordinasi pengawasan antar lembaga dan belum solidnya sistem whistleblowing yang dimplementasikan. Paper ini menawarkan penguatan pengendalian internal dan whistleblowing system yang terintegrasi agar permasalahan sistem pengawasan dana desa bisa diselesaikan dengan baik.
\end{abstract}

Kata Kunci: $\quad$ Dana desa; Fraud; Fraud prevention; Fraud detection JEL Classification: $\quad$ M420

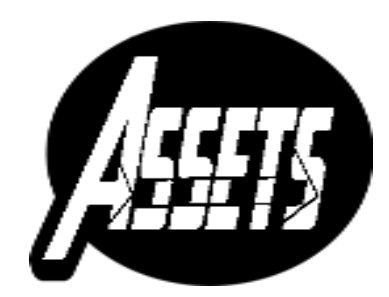

ASSETS

Jurnal Akuntansi dan Pendidikan

Vol. 9 No. 2

Page 156-170

Madiun, October 2020 p-ISSN: 2302-6251 e-ISSN: 2477-4995

Article History Submitted: August 15, 2019 Accepted:

October 24, 2020 


\section{INTRODUCTION}

The number of Village Fund rolled out has been supported by comprehensive regulations and governance (Kemenkeu, 2017). Many reports show different things about the prevalence of village heads involved in the misuse of village funds (village fund fraud). Fraud includes various acts against the law (Tuanakotta, 2010), the practice of cheating and often interpreted with irregularities (Priantara, 2013; Reurink, 2018; Tutino \& Merlo, 2019; Van Driel, 2019). The transfer of blame to village heads is naive because they also have limitations regarding literacy and understanding of the term "corruption" used by anti-corruption practitioners in Indonesia, which sociologically refers to officials' abuse for personal gain. This term emerged through describing the corruption case of the octopus president Suharto (Tuanakotta, 2010). Limited knowledge of how to avoid and comply with a set of rules governing village funds management and accountability is one of the problems (IP03; IP04, 2017).

Support for transparency and good internal control sometimes does not guarantee that a program is free from potential fraud. Based on the Village Financial Management Study Report: Allocation of Village Funds and Village Funds, the Corruption Eradication Commission (KPK) said there were several problems, including the potential for corruption/fraud from the start of the process of distributing village funds, both by village officials and assistants due to weaknesses of village officials (KPK, 2015b). There are five corruption-prone points in the process of managing village funds. These are the planning, management, implementation (procurement of goods and services in terms of distribution and management of village funds), the process of accountability and monitoring and evaluation) (Indonesia Corruption Watch, 2017). In a study conducted in January 2015, the KPK found 14 findings involving four aspects, namely regulatory and institutional aspects, management aspects, aspects of supervision, and human resources aspects (KPK, 2015a).

Law No. 6/2014 mandates layered supervision as a form of security for village funds, but based on field research, not all supervision levels work well. The same thing was also expressed, "The practice of supervision is currently still minimal, and there is no legal umbrella and regulation from the government for the supervisory process." The government's supervision regulations are still generally on the performance of the village government as a whole. Based on a preliminary study, the BPKP and the InspectorateInspectorate's supervision is carried out with a random system in each budget year due to limited personnel and lack of understanding of the Village Law and its derivatives.

Another obstacle is the absence of a delegation of authority from the Regent to the sub-district. The sub-district is still dominant in only conducting administrative supervision due to the delegation of authority and the still limited capacity of each subdistrict. Another government step to strengthen supervision is to sign a memorandum of understanding (MoU) with various parties. This step also has pros and cons. According to Indonesia Corruption Watch (ICW) data, there were 110 cases of misappropriation of village funds and village fund allocations during 2016-2017. Based on the ICW report, since 2015, 215 Village heads have been involved in dealing with the law and have been imprisoned for mismanagement of village funds (Indonesia Corruption Watch, 2017).

Researchers conducted a literature review related to research on the prevention and detection of village fund corruption since the issuance of Law Number 6 of 2014, and related research is still relatively lacking. Researchers find research 
Anantawikrama, Komang, \& Daniel (2019); Atmadja \& Saputra, (2017); and Puspasari, (2015). Research of Puspasari (2015) is more of a theoretical study for preventing village fund fraud. Atmadja \& Saputra (2017) states that apparatus competence and internal control systems significantly affect the prevention of fraud in village financial management, and morality is proven to moderate the influence of apparatus competence and internal control systems on fraud prevention village financial management.

Almost the same thing was also raised by Wijayanti \& Hanafi (2018), focusing on morality by examining the influence of many variables related to individuals and culture on the tendency to commit fraud. Wijayanti \& Hanafi (2018) 's main findings related to cultivating village government officials' good individual morality to prevent fraud. Research by Atmadja \& Saputra (2017) stated that an ineffective internal control system affects village funds' fraudulent use.

This study is different from previous research, both by Anantawikrama et al. (2019); Puspasari, (2015); Wijayanti \& Hanafi (2018). This research looks not only at the aspects of prevention but also detection efforts by authorities. This research was conducted in more depth by selecting a case study approach using interviewing techniques with related informants such as village supervisors, the Finance and Development Supervisory Agency, the Village Empowerment Service, the Inspectorate, and the village from village government officials and the village community. This research's main objective was to find a strategy to prevent and reduce fraud in village fund management. It is hoped that the results of this analysis can be used to formulate a fraud prevention strategy in channeling village funds to close the gap for fraud.

This research is based on Albrecht, Albrecht, Albrecht, \& Zimbelman (2015); Petraşcu \& Tieanu, (2014); Repousis, Lois, \& Veli (2019) states that fraud can be prevented by creating a culture of honesty, openness, and eliminating fraud opportunity. Prevention can also be done by instilling fraud awareness (Palupi \& Santoso, 2017) and internal control (Palupi \& Santoso, 2017; Taufik, 2019; Tuanakotta, 2010). In this case, Tuanakotta (2010) divides internal control into two parts, namely active internal control and second passive internal control. On the detection side, according to Albrecht et al. (2015), one way to detect fraud is to recognize the symptoms of fraud or red flags. Red flagging is an early warning system that has been used by auditors to determine the probability of financial statement fraud (Brazel, Jones, Thayer, \& Warne, 2015).

Dal Magro \& da Cunha (2017) argues that detecting red flags is important to detect fraud. This can be seen from assessing the important role of the internal auditor in assessing the risk of fraud through red flags that refer to operational activities and internal control procedures. Besides, it is suggested that internal auditors be impartial about the relevance of their perception that most of the potential fraud arises from red flags (Dal Magro \& da Cunha, 2017). Another study states that it is important to prevent fraud because detection is only needed if fraud prevention fails (Gupta \& Singh Gill, 2012).

\section{METHOD}

This research is qualitative research with a case study approach. Mahmudi (2003) mentions case studies as strategic research to develop public sector accounting. The case study approach was chosen because it is very suitable for studying local specific phenomena (local contingencies) that have implications for specific policies rather than generalities (Yin, 2015). The research was conducted in Barito Kuala Regency with 
three villages in Alalak District as critical informants for in-depth studies. The three villages were selected to represent three of the 5 (status) villages in Barito Kuala Regency, especially Alalak District. The villages selected for this research were represented in village categories: very underdeveloped, left behind, and developing according to the village category assigned by the developing village index (IDM). This research was preceded by permission from related parties, and for mutual convenience during the data mining process, the chosen villages were deliberately nominated, along with the village table, which was the study's object.

Table 1. Research Villages

\begin{tabular}{ccccc}
\hline No & Province & District & Sub-district & Village Code \\
\hline 1. & South Borneo & Barito Kuala & A & OD01 \\
2. & South Borneo & Barito Kuala & A & OD02 \\
3. & South Borneo & Barito Kuala & A & OD03 \\
\hline
\end{tabular}

Source: Ministry of Village (2019)

In addition to the nominated research villages, for informants, the researcher also codified the informants with the following details:

Table 2. Informant Table or Key Informants

\begin{tabular}{|c|c|c|c|c|c|}
\hline No & Issue & Status & Position & Instrument & $\begin{array}{c}\text { Informant } \\
\text { Code }\end{array}$ \\
\hline 1. & $\begin{array}{l}\text { Supervision of } \\
\text { Village Funds in } \\
\text { South } \\
\text { Kalimantan } \\
\text { Province }\end{array}$ & $\begin{array}{l}\text { Key } \\
\text { Informants }\end{array}$ & $\begin{array}{l}\text { Village } \\
\text { Supervisory } \\
\text { Apparatus } \\
\text { (APD) of the } \\
\text { Provincial } \\
\text { Finance and } \\
\text { Development } \\
\text { Supervisory } \\
\text { Agency (BPKP) }\end{array}$ & $\begin{array}{l}\text { Face to face } \\
\text { interview, } \\
\text { interview via } \\
\text { phone and } \\
\text { WhatsApp, } \\
\text { transect }\end{array}$ & IP03, IP04 \\
\hline 2 & $\begin{array}{l}\text { 1. Village Fund } \\
\text { Utilization } \\
\text { Study } \\
\text { 2. Supervision } \\
\text { of Village } \\
\text { Funds in } \\
\text { South } \\
\text { Kalimantan } \\
\text { Province }\end{array}$ & $\begin{array}{l}\text { Supporting } \\
\text { Informants }\end{array}$ & $\begin{array}{l}\text { District } \\
\text { Community } \\
\text { Empowerment } \\
\text { Service (PMD) } \\
\text { officials }\end{array}$ & $\begin{array}{l}\text { FGD, } \\
\text { interviews, } \\
\text { documentati } \\
\text { on }\end{array}$ & IK01 \\
\hline 3. & $\begin{array}{l}\text { Potential of } \\
\text { Village Fund } \\
\text { Fraud }\end{array}$ & $\begin{array}{l}\text { Supporting } \\
\text { Informants }\end{array}$ & $\begin{array}{l}\text { Officials of the } \\
\text { District PMD } \\
\text { Service for } \\
\text { Village } \\
\text { Government } \\
\text { Empowerment }\end{array}$ & $\begin{array}{l}\text { Interview } \\
\text { and } \\
\text { documentati } \\
\text { on }\end{array}$ & IK02 \\
\hline 4. & $\begin{array}{l}\text { 1. Supervision } \\
\text { of Village } \\
\text { Funds in }\end{array}$ & $\begin{array}{l}\text { Supporting } \\
\text { Informants }\end{array}$ & $\begin{array}{l}\text { District } \\
\text { Inspectorate } \\
\text { Representative }\end{array}$ & $\begin{array}{l}\text { Interview } \\
\text { and docu- } \\
\text { mentation }\end{array}$ & IK03 \\
\hline
\end{tabular}




\begin{tabular}{|c|c|c|c|c|c|}
\hline No & Issue & Status & Position & Instrument & $\begin{array}{l}\text { Informant } \\
\text { Code }\end{array}$ \\
\hline & $\begin{array}{l}\text { South } \\
\text { Kalimantan } \\
\text { Province } \\
\text { 2. Potential of } \\
\text { Village Fund } \\
\text { Fraud }\end{array}$ & & & & \\
\hline 5. & $\begin{array}{l}\text { Village Fund } \\
\text { Utilization } \\
\text { Study }\end{array}$ & $\begin{array}{l}\text { Supporting } \\
\text { Informants }\end{array}$ & $\begin{array}{l}\text { District PMD } \\
\text { officials }\end{array}$ & $\begin{array}{l}\text { FGD, } \\
\text { interviews, } \\
\text { documentati } \\
\text { on }\end{array}$ & IK05 \\
\hline \multirow[t]{3}{*}{6.} & $\begin{array}{l}\text { 1. Supervision } \\
\text { of Village } \\
\text { Funds in } \\
\text { South }\end{array}$ & $\begin{array}{l}\text { Key } \\
\text { Informants }\end{array}$ & Village head & $\begin{array}{l}\text { FGD, } \\
\text { interviews, } \\
\text { documentati } \\
\text { on }\end{array}$ & ID01 \\
\hline & $\begin{array}{l}\text { Kalimantan } \\
\text { Province } \\
\text { 2. Potential of } \\
\text { Village Fund }\end{array}$ & $\begin{array}{l}\text { Key } \\
\text { Informants }\end{array}$ & Village secretary & $\begin{array}{l}\text { FGD, } \\
\text { interviews, } \\
\text { documentati } \\
\text { on }\end{array}$ & ID02 \\
\hline & Fraud & $\begin{array}{l}\text { Key } \\
\text { Informants }\end{array}$ & $\begin{array}{l}\text { Chairman of the } \\
\text { BPD }\end{array}$ & $\begin{array}{l}\text { FGD, } \\
\text { interviews, } \\
\text { documentati } \\
\text { on }\end{array}$ & ID03 \\
\hline
\end{tabular}

This study's data collection was carried out from August 2017 to May 2018, including preliminary research, observation, interviews with village informants, and the BPKP Village Supervisory Apparatus. Then it continued with focus group discussions with other informants. The data collection procedure was carried out using field research notes (field logs). Sources of evidence are documents, recordings, archives, interviews, direct observation, which are then analyzed.

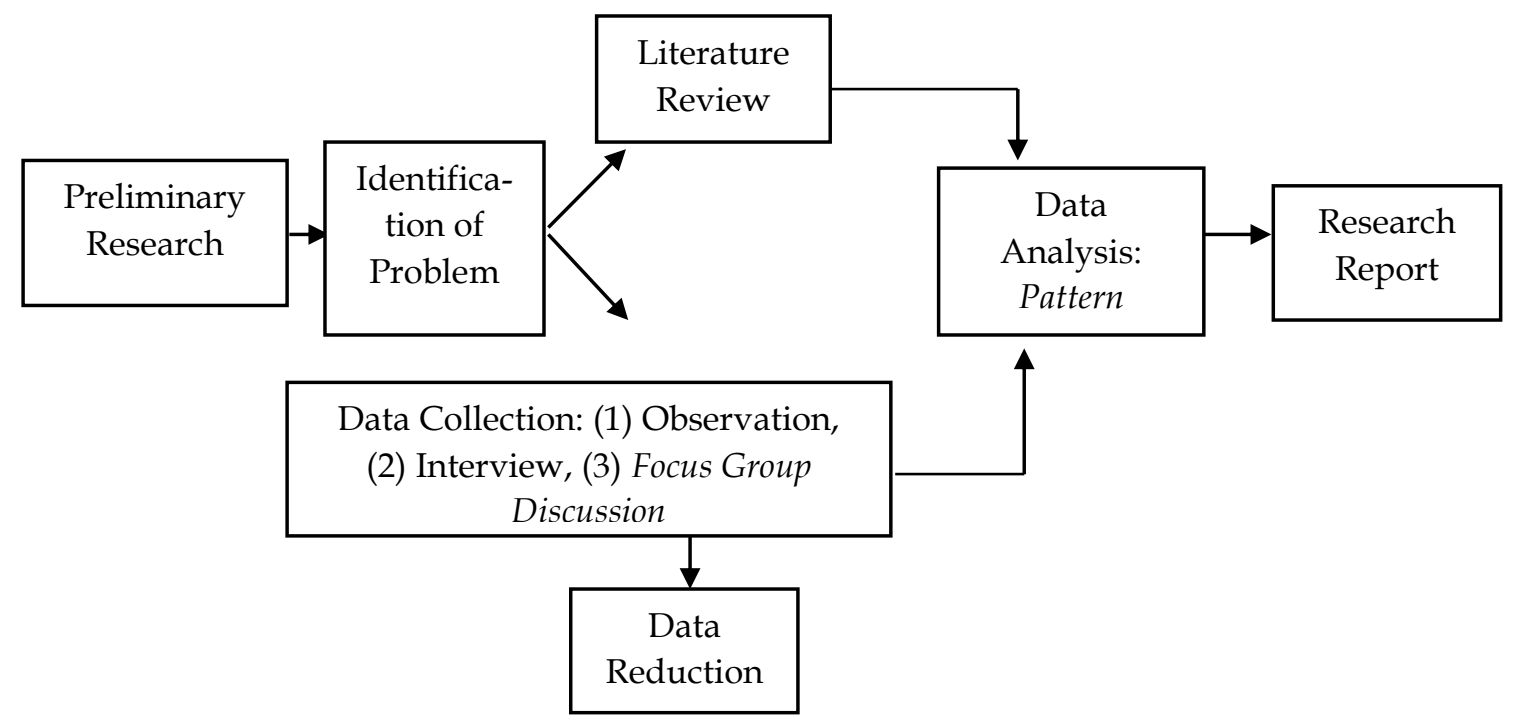

Figure 1. Research Process

Source: Developed from Yin (2015) 
According to Yin (2015), data analysis consists of testing, categorizing, tabulating, and combining evidence to refer to the initial proposition (in this study using research questions implied in the introduction) of a study. According to Yin (2015), there are five analysis techniques for the case study approach: pattern matching, explanatory building, time-series analysis, logic models, and cross-case synthesis. This study uses pattern matching to generate predictive patterns of symptoms that occur.

Pattern matching always involves an attempt to connect two patterns in which one is a theoretical pattern, and the other is an observed or operational pattern (Yin, 2015). In this study, pattern matching techniques compare patterns based on empirical data (field data) with existing patterns in theory and regulation (or with some alternative predictions).

\section{RESULT AND DISCUSSION}

\section{Distribution of Village Funds and Accompanying Impact}

The pattern of distributing village funds from 2015 to 2018 has always changed. Changes followed changes in distribution patterns in the conditions for channeling village funds. The disbursement in 2015 was not based on the performance of the distribution or use of village funds in the previous stage, and after 2016 it was required based on the previous year performance. Distribution in 2015 is carried out on conditions, including reports on realization and followed by reports on usage of the previous semester (ID02, 2018). This distribution requirement also applies in the following year. In 2018, a difference can be seen: the realization report requirement, which is a control over the management of village funds, is removed. Based on the explanation made by officials in the PMD Office of Barito Kuala Regency (2018):

"The distribution of village funds for phase I was carried out on January 29, 2018 with a total of 190 villages of Rp25.903.854.460 (97,45\%) while for phase II it was carried out on March 29, 2018 with a total of 160 villages of Rp43.619.116.120 (82,05\%)." (IK03, 2018)

The amount of Village Funds disbursed at the initial stage in Barito Kuala Regency reached $100 \%$ in the first stage due to the unconditional disbursement process as in the previous year's process. Changes in disbursement patterns in 2018 created the potential for fraud due to lax conditions. This change is indeed the result of evaluating the low absorption performance in the previous year, which was not maximized. The excess budget calculation (SiLPA) was in the Village Cash Account (RKD) (ID02, 2018). The choice not to carry out development converted the Village Fund into SiLPA in the village treasury. Disbursements that began in August were delayed due to administrative constraints.

Some conditions made village governments choose to make the Village Fund, which was distributed in stage II of 2017 in one of the villages, OD01 Village, the focus of this research. This was conveyed by one of the village officials in an interview on June 7, 2018:

"Like 2017, there were several projects that were not implemented, because the budget had only been released in December so that it was not possible to implement them so that they were made into SiLPA, this was conveyed to BPD." (ID02, 2018)

Things like this need to be prevented to avoid low absorption of the available budget. 


\section{Village Funds: Bringing Prosperity or Poverty?}

Recently, the welfare of village officials has become a central issue. Village officials' opinions are that the compensation they received was still minimal. This could be the cause of the desire to commit fraud, as conveyed by one of the Village Officials in Barito Kuala Regency during an interview on May 15, 2018:

"It is necessary to improve the welfare of village officials so that they are not tempted to commit fraud." (ID02, 2018)

a similar statement was conveyed by participants of the FGD Study of the Utilization of Village Funds in South Kalimantan on April 29, 2018:

"Compensation for village officials is very minimal. Village funds should not only benefit the village but also for village officials, so that the benefits must be expanded. The biggest benefit of village funds for village officials is dealing with Law Enforcement Officials (APH) (energy is drained, as expert witnesses)." (IK05, 2018)

The potential for fraud in the village fund originates from the budget, as seen in the description of cases in several villages in Barito Kuala Regency. Incomplete and unsupervised budget planning results in the implementation of activities that are not optimal and impact the residual use of the budget (SiLPA). The resulting impacts give rise to potential fraud in the Village Fund. A transparent, participatory, and accountable budget management is the solution to the main problems of corruption cases that occur in the village. Budget management is essential to managing the Village Fund for issuing reliable reports, so special attention is needed.

Detailed data from corruption cases regarding the modes and perpetrators cannot be explored more deeply. In general, the potential for fraud occurs among village heads and PPE, while the standard model is also found in Indonesia. This is based on research reports from Indonesia Corruption Watch (2018):

"Cases of fraud in village funds are generally administrative misappropriation, embezzlement, budget abuse, abuse of authority, illegal fees, budget inflation, fictitious reports, budget cuts, and bribery. " (Indonesia Corruption Watch, 2018)

The data should be accessible to the public.

\section{Village Funds: Tiered Guidance and Supervision}

Government Regulation Number 43 of 2014 concerning implementing regulations for Law Number 6 of 2014 concerning Villages Article 127 point J states that monitoring of Village Government administration and village development are to be carried out in a participatory manner by the village community (JDIH Ministry of Finance, 2017). Figure 2 illustrates the supervision that occurs in village funds.

Supervision operations by the district/city government are the responsibility of the Regent / Mayor. The supervisory function is delegated to the head of the subdistrict and the District / City Inspectorate by the Regent/city. The results of regent / municipal government supervision are provided to the central government on the subject of the supervision. The government also provides regulations for supervision carried out by BPD. BPD is a representation of society. BPD and the community are people who are directly involved in villages in terms of village development. They are obliged to supervise the management of the Village Fund.

The government's desire for comprehensive and adequate regulation is shown by accommodating appropriate regulations from central to regional levels. The Expert 
Auditor made this statement of the Barito Regency Inspectorate during an interview on June 4, 2018:

"Supervisory regulations are sufficient and are added to the MoU by the government which is considered positive (IK02, 2018)"

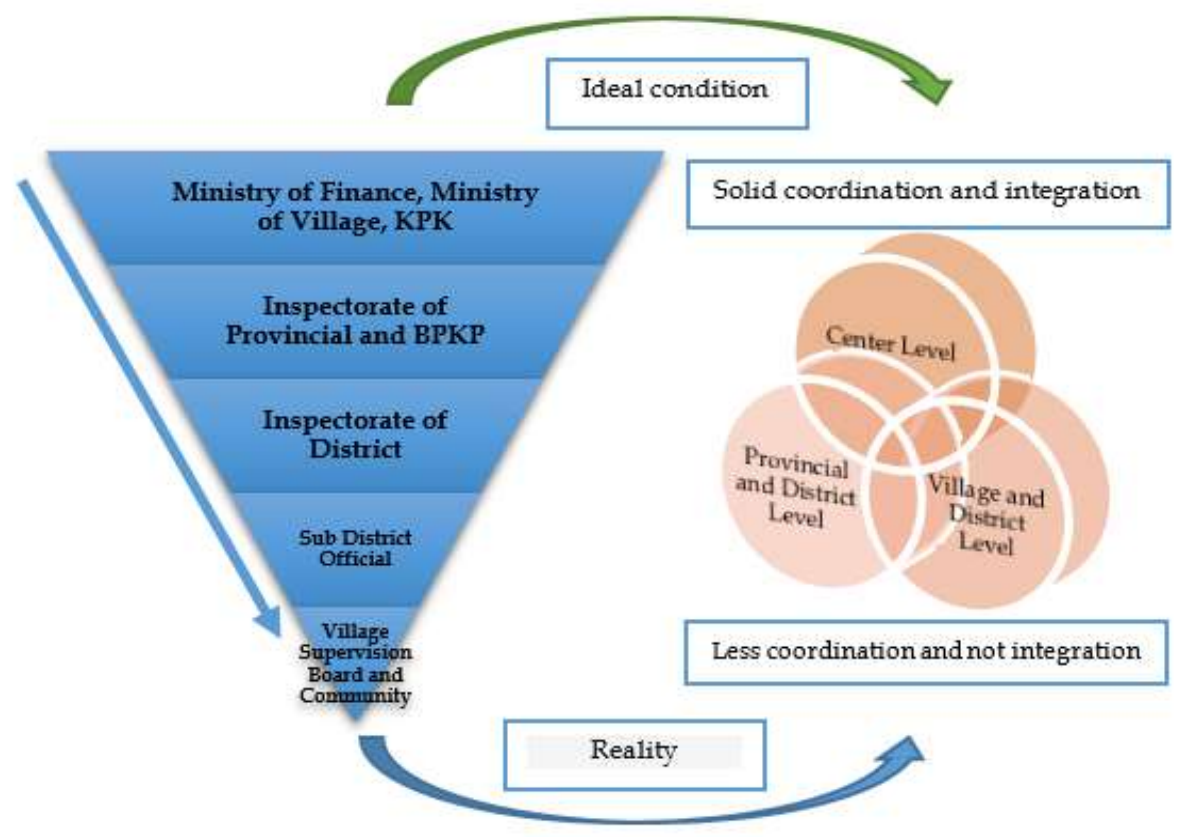

Figure 2. Tiered Supervision of Village Funds: Patterns and Reality

Several sources stated that regulations are still general, so the capacity of supervision becomes an obstacle to the implementation of supervision (IK02, 2018; IK03, 2018). At the district level in Barito Kuala, the agency that carries out supervision has undoubted capacity. It is just that the supervisory personnel are limited, and their scope of supervision is also broad, not only in the village. Supervision at the subdistrict level is constrained by capacity and personnel, and there is no devolution of authority. Capacity building and affirmation of the delegation of authority from the Regent to the District are needed to optimize supervision because the sub-district has close contact with the village. This also applies to the BPD level as an extension of the community.

Forms of Fraud Prevention and Village Fund Detection Pursued by The Government

Based on the research results in the field of BPKP and the Ministry of Home Affairs, the Inspectorate, PMD, and BPD have each prepared preventive and detection steps. Research conducted in the field and compared with the theory of fraud prevention efforts by WS Albrecht et al. (2012) is shown in Table 3.

Fraud detection has also been carried out by the supervisory agency, although it is not optimal. Table 4 shows the forms of detection efforts carried out compared to the theory of fraud detection by WS Albrecht et al. (2012).

Most theories based on Fraud Prevention and Detection have been implemented, but in practice, they cannot be part of prevention and detection ultimately. Formal supervisory agencies in South Kalimantan collaborate to carry out escorts, such as this statement from the BPKP Village Apparatus, the South Kalimantan Representative, from an interview on August 23, 2017: 
"Together with the Inspectorate, Heads of related Services and Village Officials, BPKP created a WAG (WhatsApp Group) to facilitate the coordination process." (IP03; IP04, 2017)

Table 3. Fraud Prevention Efforts Implemented

\begin{tabular}{|c|c|c|c|c|}
\hline No & $\begin{array}{c}\text { Fraud Prevention } \\
\text { Efforts }\end{array}$ & Accommodated & $\begin{array}{c}\text { Not } \\
\text { accommodated }\end{array}$ & Remarks \\
\hline 1. & $\begin{array}{l}\text { Good internal } \\
\text { control }\end{array}$ & Yes & - & $\begin{array}{l}\text { Siskuedes (IP03; } \\
\text { IP04, 2017) }\end{array}$ \\
\hline 2. & $\begin{array}{l}\text { Prevent collusion } \\
\text { between employees } \\
\text { and customers } \\
\text { (community) or } \\
\text { vendors. }\end{array}$ & - & Not & \\
\hline 3. & $\begin{array}{l}\text { Supervise and } \\
\text { provide a hotline } \\
\text { (whistleblowing } \\
\text { system) }\end{array}$ & Yes & - & $\begin{array}{l}\text { Hotline at the } \\
\text { village ministry } \\
\text { (IK01, 2018; IK03, } \\
\text { 2018; IP03; IP04, } \\
\text { 2017) }\end{array}$ \\
\hline 4. & $\begin{array}{l}\text { Create a system of } \\
\text { sanctions }\end{array}$ & Yes & - & $\begin{array}{l}\text { (Law No.6, 2014) } \\
\text { (IK03, 2018) }\end{array}$ \\
\hline 5. & $\begin{array}{l}\text { Conduct proactive } \\
\text { audits }\end{array}$ & Yes & - & $\begin{array}{l}\text { Special } \\
\text { Examination } \\
(\mathrm{IK} 03,2018)\end{array}$ \\
\hline
\end{tabular}

Table 4. Fraud Detection Efforts Carried Out

\begin{tabular}{lllll}
\hline No & Fraud Prevention Efforts & $\begin{array}{c}\text { Accommo } \\
\text { dated }\end{array}$ & $\begin{array}{c}\text { Not } \\
\text { accommodated }\end{array}$ & Source \\
\hline 1. & Identify possible fraud & Yes & - & $\begin{array}{l}\text { Special Examination } \\
\text { (IK03, 2018) } \\
\text { 2. }\end{array}$ \\
$\begin{array}{l}\text { Map possible fraud } \\
\text { symptoms (red flag) }\end{array}$ & - & Not & $($ IK03, 2018) \\
\hline
\end{tabular}

The collaboration carried out by BPKP, and cooperating institutions started with central and regional levels as the first step to guarding village funds. In 2017 BPKP collaborated with the Ministry of Home Affairs to develop and launch the Village Financial System (SISKEUDES).

SISKEUDES is used nationally. Previously Barito Kuala District used the Simpekdes application, which was developed independently. This is different from SISKEUDES, which was created by the BPKP and the Ministry of Home Affairs. SISKEUDES produces reports by established regulations and mechanisms to allow the government to assist village officials in preparing village financial reports that are more transparent and accountable. The government claims SISKEUDES is a form of potential Village Fund fraud prevention and suppression. SISKUEDES was also mentioned as part of the Implementation of Internal Control, but several sources stated that SISKEUDES could not play a role in Internal Control.

The government has created complaints channels through the village task force. There is a hotline (1500040) and a website (https://satgas.kemendesa.go.id/). As of early 2019, the website was not accessible. In reality, most remote areas cannot access 
these complaints channels, and networking and education are only provided for a few parties.

The supervision at each level of control is still not optimal because there is no coordination between supervisory agencies for the follow-up process. The government has drafted regulations on the sanctions system, but several parties have seen its implementation as obstructing the village development process. According to a source in the Inspectorate of Barito Kuala Regency, periodic audits are not effective because they still use a sampling system. The detection process is carried out by identifying the possibility of fraud through a special audit, which is only conducted when there are reports of potential fraud.

\section{Potential Fraud Opportunity Patterns in the Research Subject}

For the supervisory agency to function optimally in its role in preventing and detecting fraud, staff need to understand fraud and the types of fraud that may occur. The results show that fraud was not found in the three research villages, namely Beranggas Timur Village, Pulau Sugara Village, and Tanjung Harapan Village, but the potential for fraud in the Village Fund might occur. During the research process, there was the potential for fraud. Based on studies, plus observations and interviews conducted by researchers, several identifiable conditions could trigger potential fraud. According to the hexagon fraud theory, these are based on the detection of fraud that cannot be separated from stimulus, ability, opportunity, rationalization, ego, and collusion. It is a refinement of previous fraud theories. Table 5 maps potential fraud that may occur in the research village.

Conclusions based on the results of mapping conditions and potential fraud in the research village include existing conditions that caused potential fraud in the village. The consistency is a high political cost because the village head holds total power, regulations are wrongly interpreted, village officials' knowledge of financial management is lacking, and conflicts between communities and the village government exist. These findings are in line with the statement (Indonesia Corruption Watch, 2018). Other conditions were the lack of the BPD's and the community's supervisory role and the lack of compensation received by APD. PPE not receiving direct benefits from DD also prevented the potential for fraud. According to Tuanakotta (2010) and Indonesia Corruption Watch (2018), the potential for a situation being prone to this happening depends on budget abuse/inflation, embezzlement, mark-ups, fictional reports, fictional projects, and abuse of power. The minimal supervisory roles of the BPD and the community, and the minimal compensation received by the PPE, means the PPE does not receive direct benefit from DD, creating an immense potential for fraud. This leads directly to budget abuse/inflation, embezzlement, and mark-ups. This potential was found in three villages in this research.

The potential for fraud that often occurs is related to budget abuse, embezzlement, fictitious reports, fictitious activities/projects, and budget inflation. Therefore, prevention and detection are recommended. The recommendations for prevention strategies that can be implemented include strengthening internal control. Active and passive control based on Tuanakotta (2010) Launching data in fraud cases should be used to map it and its causes and implement sanctions due to fraud regularly. This is part of internal control and will provide a deterrent (Tuanakotta, 2010). Strengthening and improving internal control can be achieved by maximizing the use of SISKEUDES, which is claimed to be the government's internal control 
system. Compensation received by the village apparatus must be increased. Periodic audits conducted by the Inspectorate and BPKP must be done to make the Village Government the subject of overall inspection without sampling. Teringrasi reporting channels should be used as a form of internal control.

Table 5. Patterns That Cause Potential Fraud Opportunities in Village Research

\begin{tabular}{|c|c|c|c|c|c|c|c|}
\hline \multirow[b]{2}{*}{ No } & \multirow[b]{2}{*}{$\begin{array}{l}\text { Actual Village } \\
\text { Conditions }\end{array}$} & \multicolumn{6}{|c|}{ Fraud Potential } \\
\hline & & $\begin{array}{l}\text { Budget } \\
\text { Abuse / } \\
\text { Inflation }\end{array}$ & $\begin{array}{c}\text { Embez } \\
\text { zleme } \\
\text { nt }\end{array}$ & Mark Up & $\begin{array}{l}\text { Fiction } \\
\text { al } \\
\text { Report } \\
\text { s }\end{array}$ & $\begin{array}{c}\text { Fictio } \\
\text { nal } \\
\text { Projec } \\
t\end{array}$ & $\begin{array}{c}\text { Abuse } \\
\text { of } \\
\text { power }\end{array}$ \\
\hline 1. & High political costs & OD01 & OD01 & OD01 & OD01 & & \\
\hline 2. & $\begin{array}{l}\text { Full power vested } \\
\text { in the village head }\end{array}$ & & & & & OD03 & $\begin{array}{l}\text { OD01 } \\
\text { OD02 } \\
\text { OD03 }\end{array}$ \\
\hline 3. & $\begin{array}{l}\text { Misinterpretation } \\
\text { of regulations }\end{array}$ & & & & & & $\begin{array}{l}\text { OD01 } \\
\text { OD02 } \\
\text { OD03 } \\
\end{array}$ \\
\hline 4. & $\begin{array}{l}\text { Lack of knowledge } \\
\text { among village } \\
\text { officials on } \\
\text { financial } \\
\text { management }\end{array}$ & & & $\begin{array}{l}\text { OD01 } \\
\text { OD02 } \\
\text { OD03 }\end{array}$ & $\begin{array}{l}\text { OD01 } \\
\text { OD02 } \\
\text { OD03 }\end{array}$ & & \\
\hline 5. & $\begin{array}{l}\text { Conflict between } \\
\text { communities and } \\
\text { village } \\
\text { government }\end{array}$ & & & OD03 & & & OD03 \\
\hline 6. & $\begin{array}{l}\text { Lack of } \\
\text { supervisory role } \\
\text { from BPD and } \\
\text { community }\end{array}$ & $\begin{array}{l}\text { OD01 } \\
\text { OD02 } \\
\text { OD03 }\end{array}$ & $\begin{array}{l}\text { OD01 } \\
\text { OD02 } \\
\text { OD03 }\end{array}$ & $\begin{array}{l}\text { OD01 } \\
\text { OD02 } \\
\text { OD03 }\end{array}$ & & & \\
\hline 7 & $\begin{array}{l}\text { Minimal } \\
\text { compensation } \\
\text { received by APD, } \\
\text { and APD not } \\
\text { receiving direct } \\
\text { benefits from DD }\end{array}$ & $\begin{array}{l}\text { OD01 } \\
\text { OD02 } \\
\text { OD03 }\end{array}$ & & $\begin{array}{l}\text { OD01 } \\
\text { OD02 } \\
\text { OD03 }\end{array}$ & & & \\
\hline
\end{tabular}

\section{Stable Mechanisms and Channels for Responding to and Reporting Fraud}

The registered reporting channel is the final recommendation given in this paper for the early detection of fraud. A reporting channel can be created using an integrated whistleblower system. This system involves all parties known as a supra village, namely the PMD Office, the Inspectorate for the Regency, District, BPD, and community levels. Those at mid-level who have established their hotlines through the village task force can work together with the system. Figure 3 illustrates a recommendation for an integrated complaints channel mechanism. 


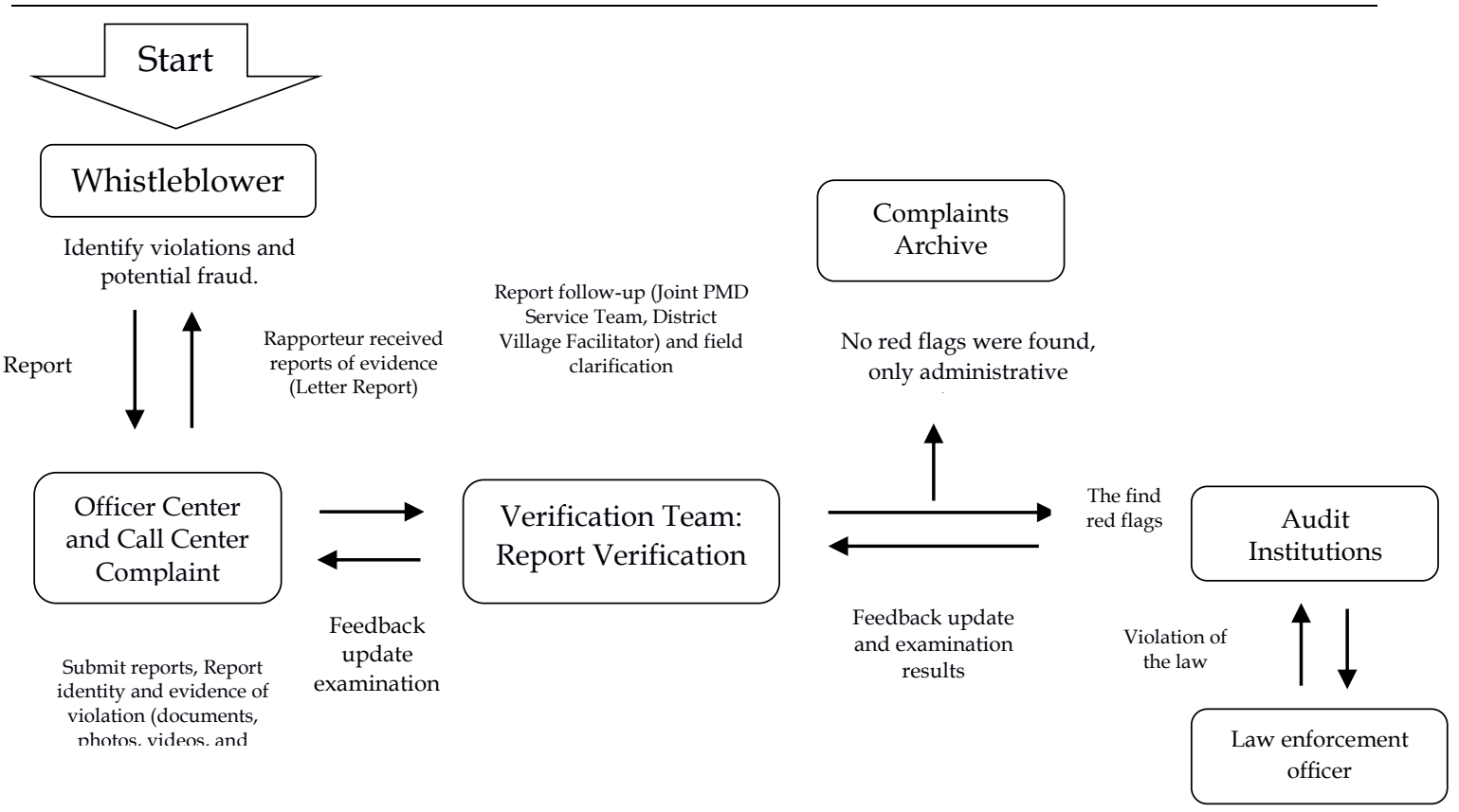

Figure 3. Recommendations for the Whistleblowing System Mechanism at the Village Level

An integrated reporting channel is established at the level closest to the village so that complaints handling can be acted upon more quickly. The process is simplified by setting up a complaints hotline. This process starts when a whistleblower (referred to as a reporter) identifies a violation / potential fraud and makes a report. Reports can be submitted online via the call center or in person. The report is processed by the verification team using the evidence submitted by the reporter. The next step will be a field assessment and cross-check of the report. The field team's cross-check determines whether the report is forwarded to the supervisory agency or just filed if it is not found. The final step is taken by APH on the audit institution's recommendation if there is a violation of the law.

A district can function as a call center and complaints office, based on the law mandate on the delegation of supervisory authority to the district head. Proximity to the village is also another balance; $\mathrm{BPD}$ and village assistants act as an initial verification team for the evidence submitted, which can then be followed up by the Village Community Empowerment Service (PMD). The field team can verify facts about the incident. The supervisory agency comprises the Inspectorate, the Financial and Development Supervisory Agency (BPKP), and the Corruption Eradication Commission (KPK) according to their capabilities. Cooperation between institutions is needed because all supervisory agencies play a role determined by their respective capabilities.

This system requires commitment and cooperation from various parties, especially the public, who are actively involved as reporters. Applicable regulations in Indonesia must protect whistleblowers. If a whistleblower makes a report, it is necessary to receive appropriate treatment, including guarantees of retaliation protection. Whistleblower reports also need to be protected and followed up by a specially formed team. Protecting witnesses and victims in Indonesia is based on Law No.13 of 2006, which concerns the protection of witnesses and victims (Lembaga Perlindungan Saksi dan Korban, 2011). 


\section{CONCLUSION}

The Indonesian government has built a village fund supervision system involving various institutions and levels of supervision, but there has been no excellent coordination among the agencies involved in practice. The Village Consultative Assembly (BPD), for example, has yet to prove its abilities regarding overseeing village funds. Before the Village Fund report is submitted to the District, the report is submitted and reviewed by the BPD management periodically from a supervisory perspective. Besides, the whistleblowing system mechanism is also not yet fully functioning. This is because there is no reliable coordination among related institutions, and the whistleblowing system has not been integrated from the village level to the central government.

Regulations and mechanisms that act as fraud prevention and detection have not been adequately implemented in the three researched villages. This is also the case in villages in Barito Kuala District. Regulations made by the government have not been implemented optimally, some are still overlapping, and ambiguity can cause fraud. The most common instances involve budget abuse, embezzlement, and mark-ups. Another researcher should use the matching pattern results in Table 4 as a variable to test the relationship of each of these patterns with efforts to prevent and detect fraud in village funds.

This research has been carried out by ethical considerations of research and scientific procedures, but there were limitations. The problem of fraud in village funds is a crucial and sensitive issue. It is not uncommon for the informants who speak to the researcher to choose a cautious attitude in providing their information, so the researchers' information may not be accurate. To solve this problem, the researcher used the triangulation method, where the data obtained from the informants were cross-checked with other data sources issued by government agencies relevant to this study.

\section{REFERENCES}

Albrecht, W. S., Albrecht, C. O., Albrecht, C. C., \& Zimbelman, M. F. (2015). Fraud Examination. In South-Western Cengage Learning (Fifth Edit). Boston, USA: Cengage Learning.

Anantawikrama, Komang, \& Daniel. (2019). Proactive Fraud Audit, Whistleblowing and Cultural Implementation of Tri Hita Karana for Fraud Prevention. European Research Studies Journal, XXII(Issue 3), 201-214. https://doi.org/10.35808/ersj/1466

Atmadja, A. T., \& Saputra, K. A. K. (2017). Pencegahan Fraud Dalam Pengelolaan Keuangan Desa. Jurnal Ilmiah Akuntansi Dan Bisnis.

Brazel, J. F., Jones, K. L., Thayer, J., \& Warne, R. C. (2015). Understanding investor perceptions of financial statement fraud and their use of red flags: evidence from the field. Review of Accounting Studies, 20(4), 1373-1406. https://doi.org/10.1007/s11142-015-9326-y

Dal Magro, C. B., \& da Cunha, P. R. (2017). Red flags in detecting credit cooperative fraud: the perceptions of internal auditors. Revista Brasileira de Gestao de Negocios, 19(65), 469-491. https://doi.org/10.7819/rbgn.v19i65.2918

Gupta, R., \& Singh Gill, N. (2012). A Data Mining Framework for Prevention and Detection of Financial Statement Fraud. International Journal of Computer Applications, 50(8), 7-14. https://doi.org/10.5120/7789-0889

ID02. (2018). Wawancara: Pembinaan dan Pengawasan Dana Desa di Desa OD01. Kabupaten Barito Kuala. 
IK01. (2018). Wawancara: (1) Studi Pemanfaatan Dana Desa (2) Pengawasan Dana Desa di

Provinsi Kalimatan Selatan. Kabupaten Barito Kuala.

IK02. (2018). Wawancara: Potensi Fraud Dana Desa. Kabupaten Barito Kuala.

IK03. (2018). Wawancara: (1) Pembinaan dan Pengawasan Dana Desa di Kabupaten Barito Kuala, (2) Potensi Fraud Dana Desa. Kabupaten Barito Kuala.

IK05. (2018). FGD: Studi Pemanfaatan Dana Desa. Kabupaten Barito Kuala.

Indonesia Corruption Watch. (2017). Cegah Korupsi Dana Desa. Retrieved August 12, 2017, from Indonesia Corruption Watch website: https://antikorupsi.org/id/news/cegah-korupsi-dana-desa

Indonesia Coruption Watch. (2018). Outlook Dana Desa 2018 Potensi Penyalahgunaan Anggaran Desa di Tahun Politik. Jakarta.

IP03;IP04. (2017). Wawancara: Pembinaan dan Pengawasan Dana Desa di Kalimantan Selatan. Banjarmasin.

JDIH Kemenkeu. Nomor 43 Tahun 2014. , Direktorat Jendral Perimbangan Keuangan Kementerian Keuangan § (2017). Indonesia: www.jdih.kemenkeu.go.id.

Kementrian Keuangan Republik Indonesia. (2017). Buku Pintar Dana Desa.

Komisi Pemberantasan Korupsi. (2015a). KPK Temukan 14 Potensi Permasalahan Pengelolaan Dana Desa.

Komisi Pemberantasan Korupsi. (2015b). Laporan Hasil Kajian Pengelolaan Keuangan Desa; Alokasi Dana Desa dan Dana Desa. In Deputi Bidang Pencegahan - KPK. Jakarta. https://doi.org/10.3406/arch.1977.1322

Lembaga Perlindungan Saksi dan Korban. (2011). Memahami Whistleblower (Cetakan I; L. S. Widiyanto, Ed.). Jakarta: Lembaga Perlindungan Saksi dan Korban (LPSK).

Mahmudi. (2003). Studi kasus sebagai strategi riset untuk mengembangkan akuntansi sektor publik. Jurnal Akuntansi \& Auditing Indonesia, 7(1), 51-65.

Palupi, D., \& Santoso, B. H. (2017). An Empirical Study on the Theory of Planned Behavior: the Effect of Gender on Entrepreneurship Intention. Journal of Economics, $\begin{array}{lllll}\text { Business } \mathcal{E} \quad \text { Accountancy } & \end{array}$ https:// doi.org/10.14414/jebav.v20i1.626

Pejabat Dinas PMD Pemerintah Kabupaten Barito Kuala. (2018). Pokok-Pokok Kebijakan Pemerintahan Kabupaten Barito Kuala. Kabupaten Barito Kuala.

Petraşcu, D., \& Tieanu, A. (2014). The Role of Internal Audit in Fraud Prevention and Detection. Procedia Economics and Finance, 16(January), 489-497. https://doi.org/10.1016/s2212-5671(14)00829-6

Priantara, D. (2013). Fraud Auditing \& Investigation. Jakarta: Mitra Wacana Media.

Puspasari, N. (2015). Fraud Theory Evolution and Its Relevance To Fraud Prevention in the Village Government in Indonesia*. Asia Pacific Fraud Journal, 1(2), 177. https://doi.org/10.21532/apfj.001.16.01.02.15

Repousis, S., Lois, P., \& Veli, V. (2019). An investigation of the fraud risk and fraud scheme methods in Greek commercial banks. Journal of Money Laundering Control, 22(1), 53-61. https:// doi.org/10.1108/JMLC-11-2017-0065

Reurink, A. (2018). Financial Fraud: a Literature Review. Journal of Economic Surveys, 32(5), 1292-1325. https://doi.org/10.1111/joes.12294

Taufik, T. (2019). The effect of internal control system implementation in realizing good governance and its impact on fraud prevention. International Journal of Scientific and Technology Research, 8(9), 2159-2165.

Tuanakotta, T. M. (2010). Akuntansi Forensik \& Audit Investigatif. Jakarta: Salemba Empat.

Tutino, M., \& Merlo, M. (2019). Accounting fraud: A literature review. Risk Governance 
and Control: Financial Markets and Institutions, 9(1), 8-25. https://doi.org/10.22495/rgcv9i1p1

UU No.6. Undang-undang No. 6 Tahun 2014 Tentang Desa. , (2014).

Van Driel, H. (2019). Financial fraud, scandals, and regulation: A conceptual framework and literature review. Business History, 61(8), 1259-1299. https:// doi.org/10.1080/00076791.2018.1519026

Wijayanti, P., \& Hanafi, R. (2018). Pencegahan fraud Pada pemerintahan desa. Jurnal Akuntansi Multiparadigma, 9(2), 331-345.

Yin, R. K. (2015). Studi Kasus Design E Metode. Jakarta: Rajawali Pers. 